\title{
Different Levels of Fertilizers on Growth and Yield of Cluster Bean (Cyamopsis tetragonoloba L.) in Rainfed Area of Uttar Pradesh, India
}

\author{
Anuradha $^{1}$, Rajendra K. Singh ${ }^{2}$, Bheem Pareek ${ }^{2 *}$, Deepak Kumar ${ }^{1}$, \\ Suman Meena ${ }^{1}$ and S.K. Dubey ${ }^{3}$
}

${ }^{1}$ Department of Agronomy, Sam Higginbottom Institute of Agriculture,

Technology and Sciences, Allahabad, U.P., India

${ }^{2}$ Soil and Nano-Science Department, Defense Institute of High Altitude Research,

Leh-Ladakh, India

${ }^{3}$ Mahalanobis National Crop Forecast Centre, New Delhi-110012, India

*Corresponding author

\section{A B S T R A C T}

Cluster bean [Cyamopsis tetragonoloba (L.) Taub] popularly known as "Guar" is an important legume crop mainly grown under rain fed condition in arid and semi-regions of Rajasthan during kharif season. It is very hardy and drought tolerant crop. Its deep penetrating roots enable the plant to utilize available moisture more efficiently and thus

\section{Keywords}

Cluster bean,

Nitrogen,

Phosphorus,

Potash, PSB, Zn.

\section{Article Info}

Accepted:

15 March 2017

Available Online:

10 April 2017 offer better scope for rain fed cropping. It has high calorific and nutritive value and its seed contains $28-32 \%$ of gum. Nitrogen also plays an important role in synthesis of chlorophyll and amino acid, which contributes to the building units of protein and thus the growth of plants. Insufficient nitrogen may reduce yield drastically and deteriorates the quality of produce. Cluster bean being a legume crop which has the capacity to fix atmospheric nitrogen by its effective root nodules the major part of nitrogen is met through Rhizobium present in the root nodules. The experiment was laid out in Randomized Block Design with three replications. The experiment consisted of three level of Nitrogen (20, 15 and $10 \mathrm{~kg} / \mathrm{ha})$, Phosphorus (40, 30 and $20 \mathrm{~kg} / \mathrm{ha})$ and Potash (20, 15 and $10 \mathrm{~kg} / \mathrm{ha})$ in combination with Phosphorus Solubilizing Bacteria (PSB) and application of Zinc at 5 $\mathrm{kg} / \mathrm{ha}$. Cluster bean variety RGC-1003 was sown at $15 \mathrm{~kg} \mathrm{ha}^{-1}$ at $45 \mathrm{~cm} \times 20 \mathrm{~cm}$ spacing on 22 July 2014. Application of Nitrogen 20, Phosphorus 40 and Potash 20kg/ha in combination with Phosphorus Solubilizing Bacteria and Zinc at $5 \mathrm{~kg} / \mathrm{ha}$ recorded maximum plant height, more number of branches, more number of nodules, maximum plant dry weight, Thus availability of native and applied phosphorus increased in root zone for utilization by the plant for growth and nodulation.

\section{Introduction}

Cluster bean [Cyamopsis tetragonoloba (L.) Taub] is hardy and drought tolerant crop having deep root system which enables to utilize the available moisture more efficiently and offers to sustain under rainfed situation. It is one of the best legume crop for the climatic situation of Rajasthan because of hardy and drought tolerant nature (Kherawat et al., 2013). In India, cluster bean is mostly grown in Rajasthan, Haryana, Punjab, Uttar Pradesh and Madhya Pradesh. Rajasthan occupies first position in India both in area and production. 
It accounts for almost 82.1 per cent area and $70 \%$ production in India. Haryana and Gujarat has second and third position respectively. Rajasthan has an area of 30 lakh hectare, production of 15.46 lakh tones with a productivity of $515 \mathrm{~kg} / \mathrm{ha}$. (Anonymous 201011). Guar occupies an important role in Indian economy because of its industrial importance mainly due to the presence of gum in its endosperm (35 to $40 \%$ ). It had been grown since ancient era for various purposes viz., vegetable, green fodder, manure and feed. Green and tender pods of cluster bean are being used as a favorite vegetable in many parts of the country. It is also grown as a forage crop (Ayub et al., 2012). The pods of cluster bean are as rich in food value as that of French bean.

The composition of cluster bean is $81.0 \mathrm{~g}$ moisture, $10.8 \mathrm{~g}$ carbohydrate, $3.2 \mathrm{~g}$ protein, $1.4 \mathrm{~g}$ of fat, $1.4 \mathrm{~g}$ of minerals, $0.09 \mathrm{mg}$ thiamine, $0.03 \mathrm{mg}$ riboflavin, 47 I.U. vitamin C, 316 I.U, vitamin A (per $100 \mathrm{~g}$ of edible portion). Available outstanding nutritional value used as a feed for livestock and poultry (D'mello, 1992). It provides nutritional concentrate and fodder for cattle and adds to the fertility of soil by fixing considerable amount of atmospheric nitrogen (Singh and Usha, 2003). It can fix approx $37-196 \mathrm{~kg}$ atmospheric nitrogen per hectare per year in soil. Sometimes it is used in reclamation of saline and alkaline soils (Mahata et al., 2009). In the recent years, this crop has assumed great significance in industrial sector due to the presence of good quality of gum in the endosperm of its seed and also having 28 to 33 per cent gum. The natural polysaccharide water-soluble polymer found in the endosperm (Reddy et al., 2011), as galactomannan gum, is the chief product used in many industries (Amin et al., 2007). This crop prefers well-drained sandy loam soil, it can tolerate saline and moderately alkaline soils with $\mathrm{pH}$ ranging between 7.5 and 8.0 and in heavy soils bacterial nodulation is hampered and prefers long day condition for growth and short day condition for induction of flowering. Fertilizer and organic manures plays a vital role to achieve higher yield of cluster bean. Among different plant nutrients nitrogen is the most important nutrient for plant growth and development (Pate et al., 1977). Nitrogen as chief constituents of plant nutrition plays an important role in synthesis of chlorophyll and amino acid (MasclauxDaubresse et al., 2006) Insufficient nitrogen may reduce yield drastically and deteriorates the quality of produce specially protein content.

Cluster bean being a legume crop has the capacity to fix atmospheric nitrogen by its effective root nodules the major part of nitrogen is met through rhizobium present in the root nodules hence; crop does not require additional nitrogen for its initial growth and development stage. Phosphorus has a positive and significant effect on nodulation and crop yield (Tilak et al., 2006) also it enables the activity of rhizobia present in root nodules (Cassman et al., 1980 and Vessey, 1994). Inoculation of cluster bean seeds with phosphate solubilizing bacteria (PSB) improves nodulation, available phosphorus content of the soil and root and shoots biomass Phosphorus is the second important plant nutrients. An application of phosphorus influences symbiotic nitrogen fixation yield and quality of cluster pods.

Evaluation of the role of biofertilizer including PSB to harness their effect in enhancing crop yield will be challenging task. The short supply and recent price hike in inorganic fertilizer encouraged the use of indigenous sources like FYM which improve the soil fertility and productivity, therefore, proper nutrient management is of prime importance. The potassium is the third most important essential nutrient after nitrogen and 
phosphorus. The potassium activates more than 60 enzymes and enzymatic catalyzes the system involved in photosynthesis, metabolism and translocation of carbohydrates and proteins, membrane permeability, stomatal regulation and water utilization. Other benefits ascribed to $\mathrm{K}$ include resistance of plants against pests, disease and stresses caused by drought, frost, salinity, sodicity and in assuring improved crop quality characteristics (Kherawat et al., 2013). Zinc plays an outstanding role in synthesis of chlorophyll, protein and also regulates water absorption. Moreover, it also play role in carbohydrates metabolism and activation of various enzymes which help in inducing alkalinity tolerance in crops by enhancing $\mathrm{Na} / \mathrm{K}$ and $\mathrm{Na} / \mathrm{Ca}$ ratio. Biofertilizer is microbial inoculants of selective microorganisms like bacteria, fungi already existing in nature. It can act as soil amendments in the abandoned soil being low cost pollution free and renewable source. The largest contribution of biological nitrogen fixation to agriculture is derived from the symbiosis between legumes and Rhizobium species. The use of biofertilizers are more eco-friendly in nature.

\section{Materials and Methods}

A field experiment on "Effect of different levels of fertilizers on growth and yield of cluster bean [Cyamopsis tetragonoloba) (L.)]" was conducted at the crop research farm of Agronomy, Allahabad School of Agriculture, SHIATS, Allahabad (U.P.) during Kharif season of 2014. Climate of region is typically sub-tropical and semi-arid. Detail climate records of the study period are depicted in figure 3.1 .

The physical and chemical properties of the soil of experimental field are presented in Table 1.1. The experiment was laid out in RBD consisting of 12 treatment combinations with 3 replications and was laid out with the different treatments allocated randomly in each replication. Twelve treatments viz $\mathrm{T}_{1}$ : $\operatorname{RDF}(100 \%)+\mathrm{PSB}, \mathrm{T}_{2}: \operatorname{RDF}(100 \%), \mathrm{T}_{3}$ : RDF $(100 \%)+\mathrm{PSB}+$ zinc $(5 \mathrm{~kg} / \mathrm{ha}), \mathrm{T}_{4}: \mathrm{RDF}$ $(100 \%)+$ Non PSB+zinc $(5 \mathrm{~kg} / \mathrm{ha}), \mathrm{T}_{5}: \mathrm{RDF}$ $(75 \%)+\mathrm{PSB}, \mathrm{T}_{6}: \mathrm{RDF}(75 \%), \mathrm{T}_{7}: \mathrm{RDF}(75 \%)$ +PSB+zinc (5kg/ha), $\mathrm{T}_{8}$ : RDF $(75 \%)+$ zinc $(5 \mathrm{~kg} / \mathrm{ha}), \mathrm{T}_{9}: \mathrm{RDF}(50 \%)+\mathrm{PSB}, \mathrm{T}_{10}: \mathrm{RDF}$ $(50 \%), \mathrm{T}_{11}: \mathrm{RDF}(50 \%)+\mathrm{PSB}+\mathrm{zinc}(5 \mathrm{~kg} / \mathrm{ha})$, $\mathrm{T}_{12}$ : RDF (50\%) +zinc (5kg/ha). The seeds were treated with bavistin @ $3 \mathrm{~g} / \mathrm{kg}$ seed and PSB culture before sowing @ $500 \mathrm{~g} / \mathrm{ha}$ with the help of $1 / 2 \mathrm{~kg}$ guar to prevent seed borne disease.

Cyamopsis tetragonoloba cv. RGS-1003 variety was used for sowing which takes around 95-100 days to mature. Seeds were sown in line manually with the spacing of plant to plant $20 \mathrm{~cm}$ and row to row $45 \mathrm{~cm}$ and depth at 3-4 cm. Plant height, Number of branches per plant (Five plants were selected randomly from each plot and measured at 20 DAS, 40 DAS, 60 DAS, and 80 DAS and 100 DAS), Number of nodules per plant, Dry weight of plant $(\mathrm{g})$ after harvesting, Crop growth rate $\left(\mathrm{g} \mathrm{m}^{-2} \mathrm{day}^{-1}\right)$ using the formula given by Brown, 1984. Crop Growth Rate = $\mathrm{W}_{2}-\mathrm{W}_{1} / \mathrm{t}_{2}-\mathrm{t}_{1}$, Where, $\mathrm{W}_{1}=$ Initial dry weight of plant $(\mathrm{g}), \mathrm{W}_{2}=$ Final dry weight of plant $(\mathrm{g}), \mathrm{t}_{1}=$ Initial time period, $\mathrm{t}_{2}=$ Final time period. Relative Growth Rate (RGR) was described by Rad ford (1967), which indicates the increase in dry weight per unit dry matter over any specific time interval and it was calculated by the following equation: Relative Growth Rate $(\mathrm{RGR})=\log _{\mathrm{e}} \mathrm{W}_{2}-\log _{\mathrm{e}} \mathrm{W}_{1} / \mathrm{t}_{2}-\mathrm{t}_{1}$, Where, $\log _{\mathrm{e}} \mathrm{W}_{1}=$ natural $\log$ of initial $\left(\mathrm{t}_{1}\right)$ dry weight $(\mathrm{g})$ of the plant, $\log _{\mathrm{e}} \mathrm{W}_{2}=$ natural $\log$ of dry weight $(\mathrm{g})$ of the plants after an interval of time $\left(\mathrm{t}_{2}\right), \mathrm{t}_{1}=$ initial time (days), $\mathrm{t}_{2}=$ time after a certain interval (days). Number of pods plant $^{-1}$, Number of grains pod ${ }^{-1}$, Test weight $(\mathrm{g})$, Grain yield $\left(\mathrm{kg} \mathrm{ha}^{-1}\right)$ and Straw yield $(\mathrm{kg}$ $\mathrm{ha}^{-1}$ ) was recorded after harvesting. Harvest 
index was obtained by dividing the economic yield (grain yield) to the biological yield (grain + Stover). The cost of cultivation for each treatment was worked out separately, taking into consideration all the cultural practices followed in the cultivation. Gross return $\left(₹ \mathrm{ha}^{-1}\right)=$ Income from grain + income from straw, Net return $\left(₹ \mathrm{ha}^{-1}\right)=$ Gross return $\left(₹ \mathrm{ha}^{-1}\right)$ - Cost of cultivation $\left(₹ \mathrm{ha}^{-1}\right)$, Benefit cost ratio $=$ Gross return $\left(₹\right.$ ha $\left.^{-1}\right) /$ Total cost of cultivation $\left(₹ \mathrm{ha}^{-1}\right)$.

\section{Results and Discussion}

\section{Growth attributes}

Observation pertaining to the effect of different levels of fertilizers on growth attributes of cluster bean is given in Figure 3.2 .

The statistical analysis of the data was found to be non significant through the crop growth stages except at 80 and 100 DAS. At 80 and 100 DAS, maximum plant height was recorded in treatment with the application of $100 \%$ recommended dose of fertilizers+PSB+Zinc ( $5 \mathrm{~kg} / \mathrm{ha})$. Ramana et al., (2011) also indicated that application of $75 \% \mathrm{RDF}+\mathrm{VAM}+\mathrm{PSB}$ significantly increase the plant height and branches per plant. The findings agrees with the previous results of Choudhary et al., (2006), Rathore et al., (2007) and Deshmukh et al., (2014). Highest number of branches, no. of nodules, and dry weight was recorded in RDF (100\%) $+\mathrm{PSB}+$ zinc $\left(5 \mathrm{~kg} \mathrm{ha}^{-1}\right)$. Moreover, maximum dry weight at 100DAS was also recorded in similar treatment [RDF $(100 \%)+\mathrm{PSB}+\mathrm{zinc}$ $\left(5 \mathrm{~kg} \mathrm{ha}^{-1}\right]$, similar findings were noticed by Rathore et al., (2007) his finding revealed that the application of $20 \mathrm{~kg} \mathrm{~N}$ and $40 \mathrm{~kg} \mathrm{P}_{2} \mathrm{O}_{5} /$ ha significantly improved the plant height, dry matter accumulation and leaf area in cluster bean than lower doses of $\mathrm{N}$ and P. Finding of Ramana et al., (2011) also indicated that application of $75 \%$ RDF+VAM+PSB significantly increase the plant height and branches per plant. Choudhary (2006) observed that application of zinc fertilization up to $5 \mathrm{~kg} / \mathrm{ha}$ significantly increased the plant height, no of branches per plant, dry matter accumulation in cluster bean. Similar findings recorded by Patel et al., (2013) he observed that application of $40 \mathrm{~kg}$ phosphorus significantly maximum number of branches per plant, plant spread, no of nodules per plant and dry matter per plant.

\section{Development attributes}

Observations in respect to the effect of different levels of fertilizers on development attributes of cluster beans are given in Figure 3.3. The data on crop, Crop Growth Rate ( $\mathrm{g}$ $\mathrm{m}^{-2}$ day $^{-1}$ ) was recorded at 0-20, 20-40, 40-60, 60-80 and 80-100 DAS though the change was non-significant through all growth stages.

At 80 to 100 DAS interval the highest CGR was observed in treatment 7 in which applied $\mathrm{RDF}(75 \%)+\mathrm{PSB}$ along with $\mathrm{Zn}(5 \mathrm{~kg} / \mathrm{ha})$; at 60 to 80 DAS interval maximum CGR was recorded in treatment 9 in which applied $\mathrm{RDF}(50 \%)+\mathrm{PSB}+\mathrm{zinc}(0 \mathrm{~kg} / \mathrm{ha})$ at 40 to 60 DAS interval maximum CGR was recorded in treatment 3 in which applied RDF $(100 \%)+P S B+z i n c(5 \mathrm{~kg} / \mathrm{ha})$ while at 20 to 40 DAS interval maximum CGR was recorded in treatment 6 in which applied $\operatorname{RDF}(75 \%)+$ Non $\mathrm{PSB}+\mathrm{zinc}(5 \mathrm{~kg} / \mathrm{ha})$. At 0 to $15 \mathrm{DAS}$ interval the highest CGR was observed in treatment 3 in which applied $\mathrm{RDF}(100 \%)+\mathrm{PSB}+\mathrm{zinc}$ (5kg/ha). Observation regarding the Relative growth rate $\left(\mathrm{g} \mathrm{g-}^{1} \mathrm{day}^{-1}\right)$ at 20-40, 40-60, 6080 and 80-100 DAS was also non-significant through all growth stages. 
Table.1 Yield and yield attributing characters of cluster bean crop in different dosages of fertilizers

\begin{tabular}{|c|c|c|c|c|c|c|}
\hline \multirow[b]{2}{*}{ Treatments } & \multicolumn{2}{|c|}{100 DAS } & \multirow{2}{*}{$\begin{array}{c}\text { Test } \\
\text { weight }\end{array}$} & \multirow[b]{2}{*}{ Grain yield } & \multirow[b]{2}{*}{ Stover Yield } & \multirow{2}{*}{$\begin{array}{c}\text { Harvest } \\
\text { Index }\end{array}$} \\
\hline & $\begin{array}{l}\text { No of } \\
\text { grains }\end{array}$ & $\begin{array}{c}\text { No. of } \\
\text { Pods }\end{array}$ & & & & \\
\hline \multirow{2}{*}{$\mathbf{T 1}$} & 5.60 & 61.67 & 26.73 & 1336.67 & 3341.67 & 28.58 \\
\hline & \pm 0.40 & \pm 0.42 & \pm 1.27 & \pm 20.82 & \pm 52.04 & \pm 1.02 \\
\hline \multirow{2}{*}{$\mathbf{T} 2$} & 5.93 & 59.07 & 26.47 & 1336.67 & 3566.67 & 27.38 \\
\hline & \pm 0.46 & \pm 1.70 & \pm 0.75 & \pm 32.15 & \pm 425.25 & \pm 2.06 \\
\hline \multirow{2}{*}{ T3 } & 9.53 & 71.20 & 31.93 & 1413.33 & 4240.00 & 25.00 \\
\hline & \pm 0.12 & \pm 0.53 & \pm 0.40 & \pm 25.15 & \pm 75.50 & \pm 2.00 \\
\hline \multirow{2}{*}{ T4 } & 6.33 & 60.67 & 26.90 & 1336.67 & 3381.67 & 28.33 \\
\hline & \pm 0.81 & \pm 2.47 & \pm 1.82 & \pm 40.41 & \pm 63.31 & \pm 1.09 \\
\hline \multirow{2}{*}{ T5 } & 5.60 & 60.40 & 27.00 & 1333.33 & 3333.33 & 28.38 \\
\hline & \pm 0.60 & \pm 1.71 & \pm 0.46 & \pm 30.55 & \pm 76.38 & \pm 1.05 \\
\hline \multirow{2}{*}{ T6 } & 6.07 & 61.47 & 27.53 & 1326.67 & 3317.33 & 28.56 \\
\hline & \pm 0.64 & \pm 1.89 & \pm 1.16 & \pm 25.17 & \pm 63.06 & \pm 1.01 \\
\hline \multirow{2}{*}{$\mathbf{T 7}$} & 8.53 & 68.67 & 30.83 & 1393.33 & 3951.67 & 26.19 \\
\hline & \pm 0.12 & \pm 0.42 & \pm 0.76 & \pm 25.17 & \pm 458.32 & \pm 2.06 \\
\hline \multirow{2}{*}{ T8 } & 6.00 & 60.00 & 27.67 & 1343.33 & 3399.67 & 28.31 \\
\hline & \pm 0.92 & \pm 1.40 & \pm 1.76 & \pm 40.41 & \pm 43.66 & \pm 1.10 \\
\hline \multirow{2}{*}{ T9 } & 5.60 & 60.00 & 26.87 & 1326.67 & 3326.67 & 28.50 \\
\hline & \pm 0.35 & \pm 1.22 & \pm 1.21 & \pm 30.55 & \pm 70.24 & \pm 0.97 \\
\hline \multirow{2}{*}{ T10 } & 6.47 & 58.60 & 27.23 & 1333.33 & 3339.00 & 28.53 \\
\hline & \pm 1.33 & \pm 0.87 & \pm 1.32 & \pm 15.28 & \pm 26.89 & \pm 1.07 \\
\hline \multirow{2}{*}{ T11 } & 7.00 & 67.07 & 29.83 & 1376.67 & 3903.33 & 26.19 \\
\hline & \pm 1.56 & \pm 0.46 & \pm 0.29 & \pm 20.82 & \pm 438.21 & \pm 2.06 \\
\hline \multirow{2}{*}{ T12 } & 5.47 & 58.80 & 26.50 & 1330.00 & 3325.00 & 27.38 \\
\hline & \pm 0.76 & \pm 2.09 & \pm 0.80 & \pm 26.46 & \pm 66.14 & \pm 2.06 \\
\hline
\end{tabular}

Fig.1 Weather parameters (climate record details of the study period)

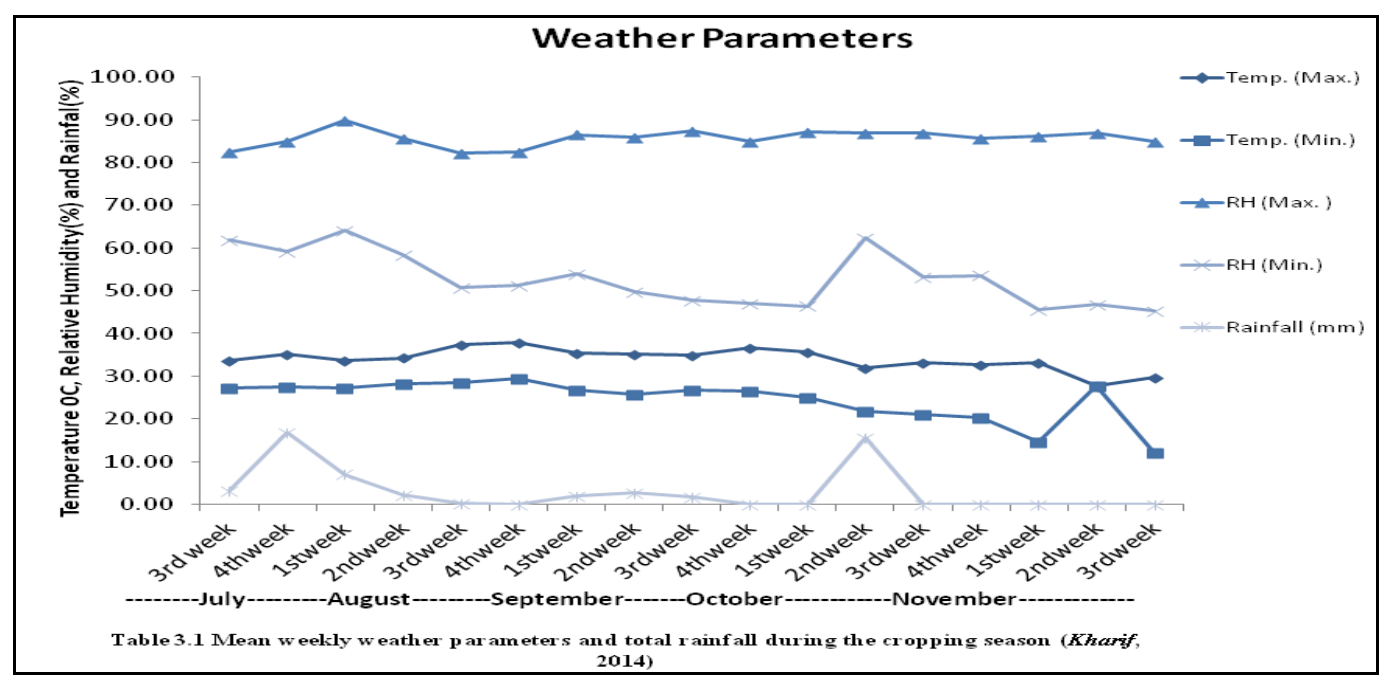


Fig.2 Crop growth parameter shows i) Plant height of cluster bean crop, ii) Dry weight of cluster bean crop, iii) Number of branches of cluster bean crop,

iv) Number of nodules of cluster bean crop

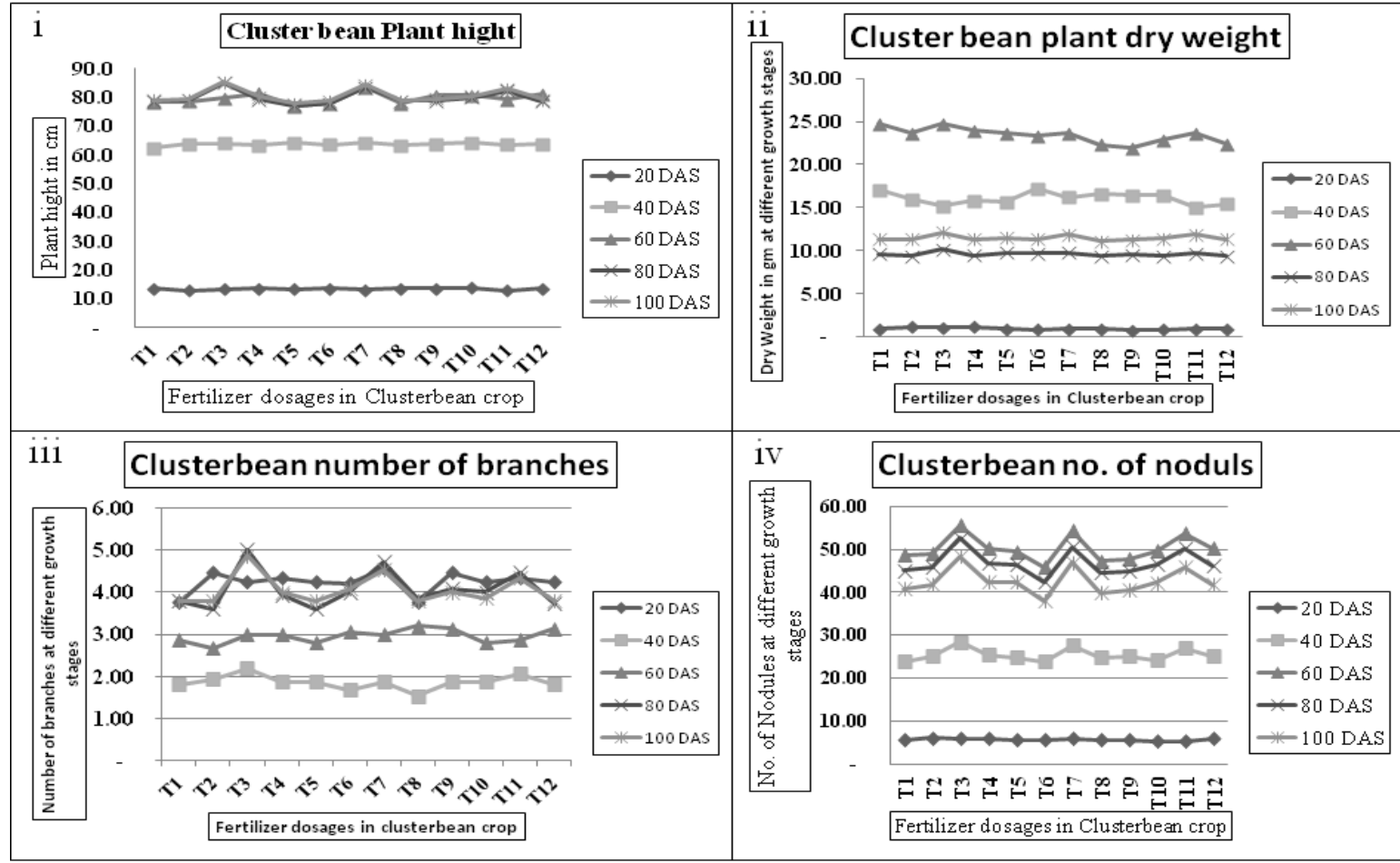

Fig.3 Crop development characters shows i) Crop growth rate of cluster bean crop, ii) Relative growth rate of cluster bean crop

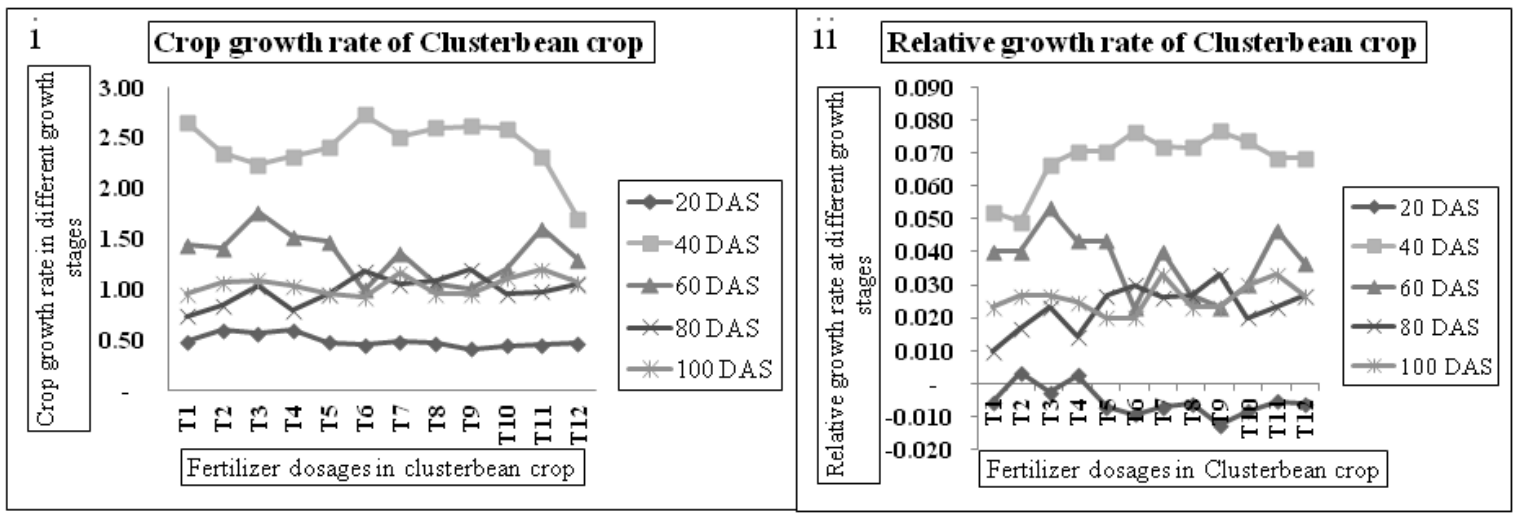

\section{Yield and yield attributes}

Observation pertaining to the effect of different levels of fertilizers on yield and yield attributes of cluster bean is given in table 3 . The significantly higher number of pods plant ${ }^{-1}$ was observed in treatment 3 in which RDF (100\%) +PSB+zinc (5kg/ha).
This treatment was found to be statistically significant as compare to rest of the treatments. Maximum number of pods per plant found with RDF (100\%) +PSB+zinc $(5 \mathrm{~kg} / \mathrm{ha})$. Increase in the number of pods plant $^{-1}$, seeds pod $^{-1}$ and seed yield with the application of $20 \mathrm{~kg} \mathrm{~N}$ and $40 \mathrm{~kg} \mathrm{P}_{2} \mathrm{O}_{5}$ in cluster bean was reported by Rathore et al., 
(2007) Increase in the yield and yield contributing parameter in cluster bean was reported by Ayub et al., (2013). Highest number of pods plant $^{-1}, 1000$ seed weight, seed yield and stover yield of cluster bean were maximum with $100 \%$ RDN through urea+Rhizobium+PSB (Kumar et al., 2012). Significantly higher number of grains pod $^{-1}$, test weight, grain yield and stover yield was observed in treatment 3 in which RDF (100\%) was applied along with PSB+zinc (5kg/ha). This treatment was found to be at par with treatment 7. Result agreed with the finding of Rathore et al., (2007), Ayub et al., (2013) and Choudhary, (2006), Meena et al., (2003) observed the increased pods per plant, seeds per pod, pod length and test weight and yield with the PSB inoculated treatments. Highest harvest index was observed in treatment 1 in which was applied RDF (100\%) + PSB+zinc (0kg/ha). Application of RDF (100\%) $+\mathrm{PSB}+$ zinc $(0 \mathrm{~kg} / \mathrm{ha})$ resulted highest harvest index at $28.58 \%$.

As for as economics of the experiment concerned the highest Gross return ( $₹$ $69253.19 \mathrm{ha}^{-1}$ ), net return (₹ $45363.54 \mathrm{ha}^{-1}$ ) and benefit cost ratio (1.89) were registered in treatment 3 in which applied 20-40-20 $\mathrm{NPK} / \mathrm{Kg} / \mathrm{ha}(\mathrm{RDF} 100 \%)+\mathrm{PSB}+$ Zinc $5 \mathrm{~kg} / \mathrm{ha}$. The results were similar finding by Kumar et al., (2012) recorded that the highest net return and Benefit Cost ratio (BCR) with the application of $100 \%$ RDN through Urea + Rhizobium + PSB .

In conclusion it is well known that adequate supply of nitrogen, phosphorus, potassium and zinc are essential to provide the better nutritional environment in the root zone for proper crop growth and development. Zinc plays role in carbohydrates metabolism and activation of various enzymes which helps in inducing alkalinity tolerance in crops enhancing $\mathrm{Na} / \mathrm{K}$ and $\mathrm{Na} / \mathrm{Ca}$ ratio. It is obvious that PSB produces organic acids which render the insoluble phosphate to soluble one. Thus the availability of native and applied phosphorus increased in root zone for utilization by the plant for growth and nodulation. It is obvious that PSB produces organic acids which render the insoluble phosphate to soluble one. It may be concluded that among the different levels of fertilizers, (100\% RDF) in combination with PSB seed inoculation and Zinc $5 \mathrm{~kg} / \mathrm{ha}$ was found to be the best for obtaining highest seed yield, net return and benefit cost ratio in cluster bean. Since the finding is based on the research carried out in single season only it may be validated for further locations and varieties.

\section{References}

Amin, A.M., Ahmad, A.S., Yin, Y.Y., Yahya, N. and Ibrahim, N. 2007. Extraction, purification and characterization of durian (Durio zibethinus) seed gum. Food Hydrocolloids, 21(2): 273-279.

Anonymous. 2010-11. Rajasthan Agriculture Statistics at a glance. Department of Agriculture Government of Rajasthan.

Ayub, M., Nadeem, M.A., Naeem, M., Tahir, M., Tariq, M. and Ahmad, W. 2012. Effect of different levels of $\mathrm{P}$ and $\mathrm{K}$ on growth, forage yield and quality of cluster bean (Cyamopsis tetragonolobus L.). $J$. Animal and Plant Sci., 22: 479-483.

Brown, R.H. 1984. Growth of the green plant. In M.B. Tesar (eds).Physiological basis of crop growth and development. Am. Soc. Agron. Medison Wisconsin, 153-174.

Cassman, K.G., Whitney, A.S. and Stockinger, K.R. 1980. Root growth and dry matter distribution of soybean as affected by phosphorus stress, nodulation, and nitrogen source. Crop Sci., 20(2): 239244.

Choudhary, M. 2006. Response of cluster bean [Cyamopsis tetragonoloba (L.) Taub] to sulphur and zinc fertilization. M.Sc. (Ag.) Thesis, Rajasthan Agricultural University, Bikaner.

Deshmukh, R.P., Nagre, P.K., Wagh, A.P. and 
Dod, V.N. 2014. Effect of Different Biofertilizers on Growth, Yield and Quality of Cluster bean Indian J. Adv. Plant Res., 1(2): 39-42.

D'mello, J.P.F. 1992. Chemical constraints to the use of tropical legumes in animal nutrition. Animal Feed Sci. Technol., 38(2-3) 237-261.

Kherawat, B.S., Munna Lal, Agarwal, M., Yadav, H.K., and Kumar, S. 2013. Effect of Applied Potassium and Manganese on Yield and Uptake of Nutrients by Cluster bean (Cyamopsis tetragonoloba). J. Agri. Physics, 13(1): 22-26.

Mahata, K.R., D.P. Singh, and A.M. Ismail. 2009. "Crop and natural resource management for high and stable productivity in coastal saline areas." Limited Proceedings.

Masclaux-Daubresse, C., Reisdorf-Cren, M., Pageau, K., Lelandais, M., Grandjean, O., Kronenberger, J., Valadier, M.H., Feraud, M., Jouglet, T. and Suzuki, A. 2006. Glutamine synthetase-glutamate synthase pathway and glutamate dehydrogenase play distinct roles in the sink-source nitrogen cycle in tobacco. Plant Physiol., 140(2): 444-456.

Meena, R., Jat, N.L. and Meena, N.L. 2003. Effect of phosphorus and biofertilizers (Rhizobium and PSB) on yield and quality of cluster bean (Cyamopsis tetragonoloba). Annals of Agri. Res., 24(1): 145-147.

Pate, J.S., Sharkey, P.J. and Atkins, C.A. 1977. Nutrition of a developing legume fruit functional economy in terms of carbon, nitrogen, water. Plant Physiol., 59(3): 506-510.

Patel, H.R., Patel, H.F., Maheriya, V.D., and
Dodia, I.N. 2013. Response of kharif green gram (Vigna radiata L. Wilczek) to sulphur and phosphorus fertilization with and without biofertilizer application. The Bioscan, 8(1): 149-152.

Radford, P.J. 1967. Growth analysis formulae: their use and abuse, Crop Sci., 7: 171175.

Ramana, V., Ramakrishna. M., Purushotham, K. and Reddy, B. 2011. Effect of biofertilizers on growth, yield and quality of cluster bean. Veg. Sci., vol.38 jan-june.

Rathore, V.S., Singh, J.P., Soni, M.L. and Beniwal, R.K. 2007. Effect of nutrient management on growth, productivity and nutrient uptake of rainfed cluster bean in arid region. Indian J. Agri. Sci., 77: 349353.

Reddy, K., Mohan, G.K., Satla, S. and Gaikwad, S. 2011. Natural polysaccharides: versatile excipients for controlled drug delivery systems. Asian $J$. Pharma. Sci., 6(6): 275-286.

Singh, B. and Usha, K. 2003. Nodulation and symbiotic nitrogen fixation of cowpea genotypes as affected by fertilizer nitrogen. J. Plant Nutri., 26(2): 463-473.

Tilak, K.V.B.R., Ranganayaki, N. and Manoharachari, C. 2006. Synergistic effects of plant-growth promoting rhizobacteria and Rhizobium on nodulation and nitrogen fixation by pigeonpea (Cajanus cajan). European $J$. Soil Sci., 57(1): 67-71.

Vessey, J.K. 1994. Measurement of nitrogenase activity in legume root nodules: in defense of the acetylene reduction assay. Plant and Soil, 158(2): 151-162.

\section{How to cite this article:}

Anuradha, Rajendra K. Singh, Bheem Pareek, Deepak Kumar, Suman Meena and Dubey, S.K. 2017. Different Levels of Fertilizers on Growth and Yield of Cluster Bean (Cyamopsis tetragonoloba L.) in rainfed area of Uttar pradesh. Int.J.Curr.Microbiol.App.Sci. 6(4): 2029-2036. doi: https://doi.org/10.20546/ijcmas.2017.604.240 